\title{
NOTES
}

\section{RENESTING AND PROBABLE DOUBLE-BROODING BY NORTHERN SAW-WHET OWLS: A RESPONSE TO PREY ABUNDANCE?}

DOUGLAS VAUGHAN, 890 Keeler Avenue, Berkeley, California 94708; vaughan4@mindspring.com

The Northern Saw-whet Owl (Aegolius acadicus) nests widely in North America and is regularly reported during the breeding season (roughly February-May) in Alameda and Contra Costa counties in the San Francisco Bay area. Documented instances of breeding are scarce, however: breeding bird atlases for these counties report breeding of Northern Saw-whet Owls on only a few occasions, all in the Oakland-Berkeley hills (Glover 2009, Richmond et al. 2011). Nonetheless, from 2004 to 2015, several colleagues and I observed 19 Northern Saw-whet Owls nesting in tree-mounted boxes designed for Wood Ducks (Aix sponsa) on property managed by the East Bay Municipal Utility District (EBMUD) in Contra Costa County. The boxes are distributed over a distance of about $1500 \mathrm{~m}$ along San Pablo Creek and the adjacent shorelines of San Pablo Reservoir, in a riparian woodland of Monterey pine (Pinus radiata), coast live oak (Quercus agrifolia), California bay laurel (Umbellularia californica), and arroyo willow (Salix lasiolepis), at elevations of about 100 $\mathrm{m}$. The study site is part of an extensive area of managed watersheds and regional parks immediately east of the urban corridor on the east shore of San Francisco Bay.

During the 12 years of our observations, we banded 11 nesting adult females, as well as 42 nestlings. We did not have resources to capture or band adult males. During 2010 alone, we observed five Northern Saw-whet Owl nests among the 28 Wood Duck nest boxes we monitored regularly. Two of these nests represent a likely instance of double-brooding. I am not aware of previous reports of double-brooding by wild Northern Saw-whet Owls (see, for example, Marks et al. 2015).

Rasmussen et al. (2008) reported dates of clutch initiation by the Northern Sawwhet Owl ranging from late February to July and speculated that June and July dates likely reflect second clutches or replacement clutches. In our study area, between 2004 and 2009, and again in 2011 and 2015, egg-laying in the nests we observed typically began in March, usually early March, and only once as late as April. In 2010 three nests were established by early March, but two (the "late" nests) were initiated in May. In 2012 two unsuccessful nests were established in early March and a third, successful nest was established in mid-April.

The first of the late 2010 nests (nest 10-4, the fourth nest of 2010) was established on or about 4 May and was the second nest of a female banded on 13 April in a nest box (nest 10-1) about $180 \mathrm{~m}$ distant. Only eight days elapsed between the last observation of three well-developed nestlings, estimated to be about three weeks old, in nest 10-1 (26 April) and observation of the first egg in nest 10-4 (4 May). We found one nestling dead in nest 10-1 on 4 May; I presume the other two fledged. Therefore I believe this pair of nests represents an instance of successful double-brooding (four nestlings apparently fledged from nest 10-4, on or about 4 July). Owing in part to restrictions on nighttime access to the watershed, we have never observed dependent young outside their nests, nor have we recaptured birds that were banded as nestlings; nonetheless, I inferred successful fledging when I found a nest vacant after following the nestlings to an age of three to four weeks (see Marks et al. 2015). Predation just prior to fledging is unlikely, as we saw evidence of possible mammalian predation only once (of Wood Duck eggs in a nest box with an unsecured lid) in more than 175 Northern Saw-whet Owl and Wood Duck nests. 


\section{NOTES}

The behavior of captive Northern Saw-whet Owls further supports the likelihood of double-brooding in this case. Krahe (2001, cited in Rasmussen et al. 2008) reported that captive birds established second nests even before the fledging of a first brood; post-fledging responsibilities for the first brood were left to the male. In addition, polygyny has been observed in wild Northern Saw-whet Owls in Idaho (Marks et al. 1989) and Oregon (Marks et al. 2005), demonstrating a male's ability to provision two or more broods simultaneously. Accordingly, I conclude that a single male, given sufficient resources, is capable of providing for both an incubating female and two recent fledglings. On the other hand, Cannings (1993) suggested the possibility of sequential polyandry in the Northern Saw-whet Owl, though in our case the proximity of the two nests would seem to make this scenario less likely. Notably, in Europe Solheim (1983, cited in Hayward and Hayward 1993) documented both bigyny and biandry in the closely related Boreal Owl (A. funereus) when vole populations were high.

The second late nest that we observed in 2010 (nest 10-5), established in late May, was located about $70 \mathrm{~m}$ from an early-season nest (nest 10-3) where three nestlings failed to survive to two weeks. We were unable to band the female observed on this first, unsuccessful nest, hence I cannot judge whether the same female was the successful nester in nest 10-5. Roughly one month elapsed between the failure of nest 10-3 and the commencement of egg-laying in nest 10-5. The last two of four apparent fledglings left nest 10-5 between 29 July and 6 August.

In 2012 the late nest was established in mid-April one to two weeks after the abandonment of a clutch about $50 \mathrm{~m}$ away. Again we were unable to band the female on the first nest and thus cannot confirm that she was the successful nester on the later nest.

The heightened nesting activity in 2010 , especially the two late nests, suggested the possibility of an unusual abundance of prey. Accordingly, I removed the debris from the two late 2010 nests and identified the prey remains, which, in the Northern Sawwhet Owl, accumulate after the adult female leaves the nest for day roosts elsewhere, typically when the nestlings are two to three weeks old (Rasmussen et al. 2008). The results are shown in Table 1, together with results from 2011 (two nests), 2012 (one nest), and 2015 (one nest). The relative abundance of potential prey species varied widely from year to year. The variation in abundance of the California vole (Microtus californicus), in particular, is most easily explained by an irruption of voles in 2010 and a less dramatic spike in the vole population in 2012-though I do not know of any local multiyear rodent-abundance surveys to quantify this variation. In nearby areas that have been intensively studied in the past, however, population densities of voles can vary by more than tenfold in cycles lasting two to five years (Cockburn and Lidicker 1983, Salvioni and Lidicker 1995). Such an irruption should provide the owls not only more prey but also heavier prey: the mass of adult California voles is 35-72 g, that of the two most common local species of deer mice (Peromyscus maniculatus and P. truei) is 14-29 g (Jameson and Peeters 2004).

The apparent difference in vole abundance we observed cannot be attributed to the different times the prey remains accumulated-June and July in 2010 and 2012, April and May in 2011 and 2015. Substantial numbers of voles in late June and July point to an irruption that would have carried over from the spring, whereas low numbers in April and May indicate that vole numbers were never high that year (Cockburn and Lidicker 1983).

In Idaho and British Columbia breeding Northern Saw-whet Owls have been found to respond nomadically to variations in small-rodent numbers (Marks and Doremus 2000, Bowman et al. 2010). We have too little data to judge the likelihood of nomadism in our area: the number of early-season nests we found between 2004 and 2015 varied from zero (in 2005 and 2013) to three (in 2010); in nine of the twelve years, the number was one or two. The observations of renesting and probable doublebrooding, however, suggest an alternative response to increases in prey abundance. 
NOTES

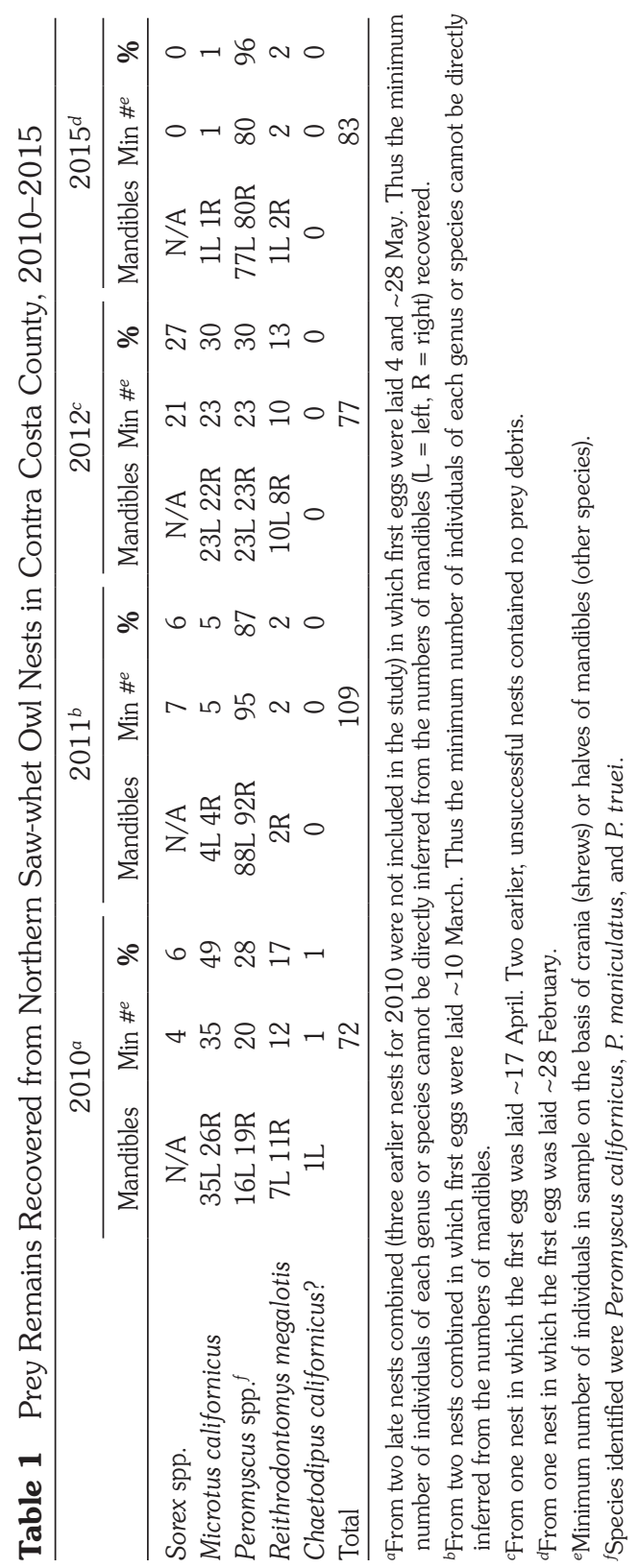




\section{NOTES}

By continued monitoring, I hope to clarify the relationship between renesting and vole irruptions in the San Francisco Bay area.

I owe special thanks to William Z. Lidicker, Jr., for his reading of an earlier draft manuscript, conversations regarding rodent populations in the Bay Area, and especially his patient willingness to identify prey remains from the Northern Saw-whet Owl nests in 2010. Thanks also to Tim Manolis, Hans Peeters, David E. Quady, and S. G. Sealy for discussions and close readings of earlier versions of this manuscript, and to Daniel S. Cooper and Lance A. M. Benner for their thoughtful reviews of the final manuscript. I am also grateful to Robert Bartholomew and Doris Kretschmer, who shared in monitoring efforts over the years, to Sandra J. Ferriera, who banded the owls, and to EBMUD and its employees for providing the access and assistance that made these observations possible. The California Wood Duck Program of the California Waterfowl Association established and continues to support nest-box monitoring on the EBMUD watershed.

\section{LITERATURE CITED}

Bowman, J., Badzinski, D. S., and Brooks, R. J. 2010. The numerical response of breeding Northern Saw-whet Owls Aegolius acadicus suggests nomadism. J. Ornithol. 151:499-506; doi 10.1007/s10336-009-0482-3.

Cannings, R. J. 1993. Northern Saw-whet Owl (Aegolius acadicus), in The Birds of North America (A. Poole and F. Gill, eds.), no. 42. Acad. Nat. Sci., Philadelphia.

Cockburn, A., and Lidicker, W. Z., Jr. 1983. Microhabitat heterogeneity and population ecology of an herbivorous rodent, Microtus californicus. Oecologica 59:167-177; doi 10.1007/BF00378834.

Glover, S. A. 2009. Breeding Bird Atlas of Contra Costa County. Mount Diablo Audubon Soc., Walnut Creek, CA.

Hayward, G. D., and Hayward, P. H. 1993. Boreal Owl (Aegolius funereus), in The Birds of North America (A. Poole and F. Gill, eds.), no 63. Acad. Nat. Sci., Philadelphia; doi 10.2173/bna.63.

Jameson, E. W., Jr, and Peeters, H. J. 2004. Mammals of California. Univ. of Calif. Press, Berkeley.

Krahe, R. 2001. Saw-whet Owl (Aegolius acadicus) and the Queen Charlotte Owl Project (Q.C.O.P.). Society for the Conservation of Owls Annual Report 2001.

Marks, J. S., and Doremus, J. H. 2000. Are Northern Saw-whet Owls nomadic? J. Raptor Res. 34:299-304.

Marks, J. S., Doremus, J. H., and Cannings, R. J. 1989. Polygyny in the Northern Saw-whet Owl. Auk 106:732-734.

Marks, J. S., Nightingale, A., and McCullough, J. M. 2015. On the breeding biology of Northern Saw-whet Owls (Aegolius acadicus), J. Raptor Res. 49:486-497; doi 10.3356/rapt-49-04-486-497.1.

Rasmussen, J. L., Sealy, S. G., and Cannings, R. J. 2008. Northern Saw-whet Owl (Aegolius acadicus), in The Birds of North America Online (A. Poole, ed.). Cornell Lab. Ornithol., Ithaca, NY; doi 10.2173/bna.42.

Richmond, B., Green, H., and Rice, D. C. 2011. Alameda County Breeding Bird Atlas. Golden Gate and Ohlone Audubon Socs., Berkeley and Hayward, CA.

Salvioni, M., and Lidicker, W. Z., Jr. 1995. Social organization and space use in California voles: seasonal, sexual, and age-specific strategies. Oecologia 101:426-438; doi 10.1007/BF00329421.

Solheim, R. 1983. Bigyny and biandry in the Tengmalm's Owl. Ornis Scand. 14:51-57; doi 10.2307/3676251. 